\title{
A new dark-saddled species of Hypostomus (Siluriformes: Loricariidae) from the upper rio Paraguay basin
}

\author{
Cláudio Henrique Zawadzki ${ }^{1}$, Claude Weber ${ }^{2}$ and Carla Simone Pavanelli ${ }^{1}$
}

\begin{abstract}
A new Hypostomus species is described from the rio Cuiabá, upper rio Paraguay basin, Mato Grosso State, Brazil. The new species is distinguished from all other Hypostomus species, with exception of young specimens of $H$. latifrons, by the presence of a wide dark transverse bars on laterals of body and fins; and conspicuous dark vermiculations on abdominal region. From $H$. latifrons it differs by having just one pre-dorsal plate surrounding supraoccipital bone and by the maintenance of the dark saddles in adults. Added to the other fish species recently described from the upper rio Paraguay basin, this work helps to highlight that the region still functions as a potential source of new species.
\end{abstract}

Uma espécie nova de Hypostomus é descrita do rio Cuiabá, bacia do alto rio Paraguai, Estado do Mato Grosso, Brasil. A espécie nova é diagnosticada de todas as outras congêneres, com exceção de H. latifrons, pela presença de amplas barras escuras transversais nas laterais do corpo e nadadeiras, e pelas conspícuas vermiculações escuras na região abdominal. De H. latifrons ela difere por ter somente uma placa pré-dorsal margeando o osso supraoccipital e pela manutenção das barras escuras transversais nos adultos. Somada a outras espécies de peixes recentemente descritas na bacia do alto rio Paraguai, este trabalho demonstra que a região ainda funciona como uma fonte potencial de espécies novas.

Key words: Armored catfish, Hypostominae, New species, Taxonomy.

\section{Introduction}

The genus Hypostomus is one of the most species-rich genus of the order Siluriformes, currently having 125 species (Weber, 2003; Zawadzki et al., 2008; Hollanda Carvalho et al., 2010). Currently, nine nominal species were described based on specimens collected in the rio Paraguay basin. Kner (1854) described H. cochliodon from Cuiabá in Brazil, Boulenger (1895) described $H$. ternetzi from "Paraguay" and soon after, Boulenger (1897) described $H$. borellii from the río Pilcomayo in Bolivia. Eigenmann \& Kennedy (1903) described $H$. boulengeri either from Mato Grosso State in Brazil or Asunción in Paraguay; Regan (1904) described H. latirostris from the rio Jangada, and Miranda Ribeiro (1912) described H. variostictus from the rio Coxim, the last two in Mato Grosso State, Brazil. Since then, a long time has passed until Weber (1986a) has described $H$. latifrons and $H$. piratatu from the río Aguarayguazú and río Tebicuary, in Paraguay, respectively. Few years later, Knaack (1999) described H. mutucae from the rio Mutuca, for Mato Grosso State, Brazil.
Hypostomus angipinnatus (Leege, 1922) decribed from "Mato Grosso (?)" has never been found in the rio Paraguay basin. The unique type specimen was not found in the Phyletisch Museum, in Jena, Germany. Moreover, three plates bordering supraoccipital (see fig. 1, in Leege, 1922) permit to diagnose $H$. angipinnatus from most of the congeners from the upper rio Paraguay basin.

Although $H$. regani (Ihering, 1905) was described from the rio Piracicaba, upper rio Paraná basin, it was collected in streams flowing into the rio Paraguay basin, in northern Paraguay (Weber et al., 1992) as well as in the rio Manso basin, upper rio Paraguay basin (Veríssimo et al., 2005; Zawadzki et al., 2009).

Recently, studying the fishes from Pantanal, Britski et al. (2007) considered the species of the genus Hypostomus to form such a complex taxonomic issue that they were not able to confidently assign any species name. In an attempt to gradually clarity this question, we are here presenting and distinguishing from the congeners a new species of the genus Hypostomus from the rio Cuiabá, upper rio Paraguay basin.

${ }^{1}$ Universidade Estadual de Maringá, Núcleo de Pesquisas em Limnologia, Ictiologia e Aquicultura. Av. Colombo, 5790, 87020-900 Maringá, PR, Brazil. claudiozawadzki@yahoo.com.br

${ }^{2}$ Département d'herpétologie et d'ichtyologie, Muséum d'histoire naturelle. Case postale 6434, CH-1211 Genève 6, Switzerland. 


\section{Material and Methods}

Specimens were collected in the rio Cuiabá, upper rio Paraguay basin, Mato Grosso State, Brazil (Fig. 1). Institutional abbreviations are based on Fricke \& Eschmeyer (2010), with the addition of Ichthyological Collection of the Universidade Federal de Rondônia (UFRO-I). Measurements and counts of bilaterally symmetrical features were taken from the left side of the body, whenever possible. Body plates nomenclature follows Schaefer (1997) and measurements follow Boeseman (1968) modified by Weber (1986b) with addition of: lower lip widest width (at maxillary barbels insertion) and lower lip length (at midline, just posterior the dentary rami to the distal border of the lip). All measurements were taken point to point with digital caliper to the nearest $0.1 \mathrm{~mm}$. The specimen ZSM 39427 was kept in aquarium after captured and photographed (the specimen later died in the aquarium and was placed in alcohol; A. Werner, pers. com.). Because this specimen rendered a good picture in life it is considered as a paratype. Therefore, due to its currently ill-conserved state it was not measured.

\section{Hypostomus peckoltoides, new species}

Figs. 2-3

Hypostomus sp.: Werner et al., 2005: 302 ("L390", photo 3; "rio Cuiabá").

Hypostomus sp. 5 - Veríssimo et al., 2007: 6 (checklist, Manso Reservoir, upper rio Paraguay basin, Brazil).

Holotype. MZUSP 105226, 110.7 mm SL, Brazil, Mato Grosso State, Municipality of Santo Antônio do Leverger, rio Cuiabá, upper rio

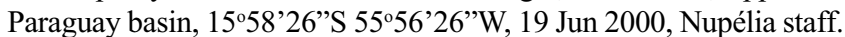
Paratypes. Same data as holotype, except when noticed. ANSP 188923, 1, $75.5 \mathrm{~mm}$ SL, 24 May 2000. MHNG 2691, 1, $82.8 \mathrm{~mm}$ SL, 24 Aug 2003. NUP 2613, 1, same data as holotype, 24 Aug 2003. NUP 5216, 2, 88.9-92.8 mm SL, 23 Aug 2000. NUP 5217, 3 , 85.5-98.2 mm SL, 20 Jun 2000. NUP 5218, 3, 80.7-86.4 mm SL. ZSM 39427, 1, $90.3 \mathrm{~mm}$ SL, rio Cuiabá, collector and date unknown.

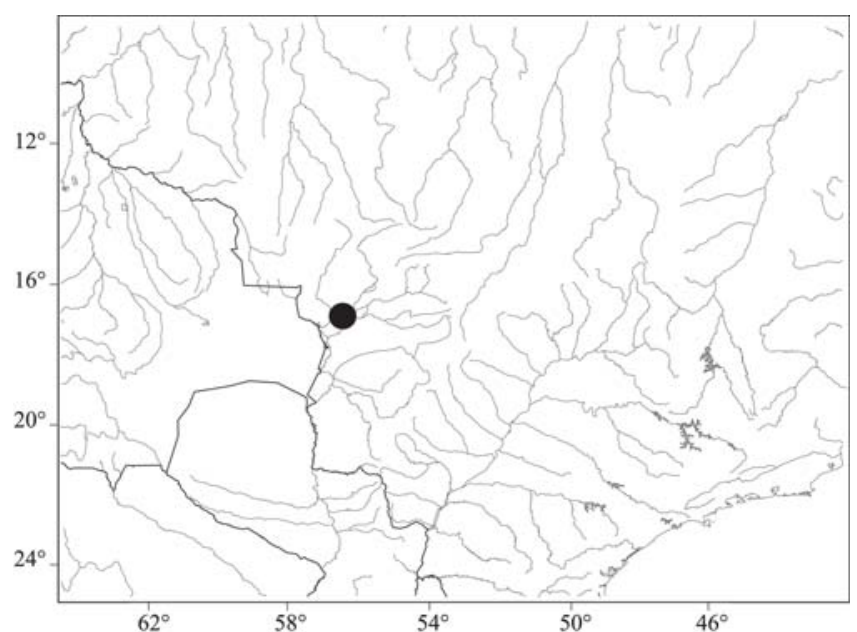

Fig. 1. Type locality of Hypostomus peckoltoides (dot), rio Cuiabá, upper rio Paraguay basin, Brazil. The symbol represents more than one lot.
Diagnosis. Hypostomus peckoltoides is distinguished from all congeners, with exception of young specimens of $H$. latifrons, by the presence of wide dark transverse bars on body and bands on the fins ( $v s$. body entirely dark or with pale or dark spots); and by the conspicuous dark vermiculations on abdominal region ( $v s$. abdominal region entirely dark or with pale or dark spots). From H. latifrons it differs by having the dark bars on the sides and bands on the fins in adults ( $v s$. spots present anteriorly and dark blotches porsteriorly in adults), and by having just one pre-dorsal plate margining the supraoccipital ( $v s$. three plates).

Description. Counts and measurements in Table 1. Head stout and slightly compressed. Body width at cleithral region considerably greater than head depth and almost equal to head length. Anterior profile of head weakly triangular in dorsal view. Eye moderately small (17.9-20.6\% of HL), latero-dorsally placed. Interorbital space straight in frontal view. Median ridge on snout slightly evident. Short, round ridges on dorsal surface of head, lateral to nares, passing above eyes and onto pteroticsupracleithrum. Pterotic-supracleithrum with slightly larger odontodes than those on remaining dermal bones. Supraoccipital with weak longitudinal median ridge and a posterior process bordered by a single plate (two fused plates to each other in one specimen). Dorsal and lateral region of body covered with dermal plates except for tip of snout and base of dorsal fin. Predorsal region with rounded and inconspicuous longitudinal ridge. Lateral surface of body with five longitudinal series of plates. Dorsal series starting just below dorsal-fin origin; weakly keeled from origin to about adipose-fin spine insertion. Mid-dorsal series weakly keeled until transverse line below insertion of last branched dorsalfin ray. Median series not keeled and bearing lateral line. Midventral series not keeled, except weak keel on first four to five plates. Ventral series weakly keeled from vertical line above anal-fin spine insertion to end of caudal peduncle.

Snout obtuse; narrowed anteriorly; elevating in lateral profile to an angle of approximately $45^{\circ}$. Dorsal profile rising abruptly from tip of snout to interorbital region and elevating convexly and more slightly from this point to dorsal-fin origin; decreasing from dorsal-fin origin to region of procurrent rays of caudal fin, then elevating again for short space until end of caudal peduncle. Caudal peduncle oval in cross-section, compressed dorsally from end of dorsal-fin insertion to origin of adipose fin and ventrally on its whole extension. Lateral line complete except for triangular plate at base of caudal.

Lips relatively small, transversally ovoid. Outer edge of upper lips without platelets. Lower lip far from reaching pectoral girdle, its inner surface covered with numerous little papillae. Maxillary barbel approximately equal to orbital diameter. Teeth relatively robust, with elongated crown and small lateral cuspid. Dentary rami form an angle of approximately $120^{\circ}$.

Lower surface of head plated laterally, with naked area extending medially from beneath lower lip to anterior border of pectoral girdle. Pectoral girdle totally plated and abdomen almost totally covered with minute platelets. 
Table 1. Morphometric data and counts of Hypostomus peckoltoides.

\begin{tabular}{|c|c|c|c|}
\hline & \multicolumn{3}{|c|}{11 specimens } \\
\hline & Holotype & Range & Mean/SD \\
\hline Standard length & 110.7 & $76.1-110.7$ & $88.8 \pm 9.36$ \\
\hline \multicolumn{4}{|c|}{ Percents of Standard length } \\
\hline Predorsal length & 41.0 & $40.0-44.4$ & $42.4 \pm 1.44$ \\
\hline Head length & 33.4 & $33.4-36.7$ & $35.2 \pm 1.15$ \\
\hline Cleithral width & 32.4 & $31.1-34.8$ & $33.4 \pm 1.14$ \\
\hline Head depth & 21.2 & $21.0-23.1$ & $21.8 \pm 0.84$ \\
\hline Interdorsal length & 15.4 & $13.1-15.5$ & $14.7 \pm 0.83$ \\
\hline Caudal-peduncle length & 31.4 & $28.1-33.8$ & $31.2 \pm 1.48$ \\
\hline Caudal-peduncle depth & 11.0 & $10.9-11.5$ & $11.1 \pm 0.24$ \\
\hline Dorsal-fin spine length & 26.2 & $26.2-35.0$ & $30.5 \pm 1.83$ \\
\hline Thoracic length & 22.6 & $21.8-26.0$ & $23.6 \pm 1.35$ \\
\hline \multicolumn{4}{|l|}{ Percents of Head length } \\
\hline Cleithral width & 97.1 & 89.95-100.6 & $94.9 \pm 3.15$ \\
\hline Head depth & 63.4 & $58.0-63.4$ & $62.1 \pm 1.73$ \\
\hline Snout length & 60.4 & $59.7-65.8$ & $62.5 \pm 1.85$ \\
\hline Orbital diameter & 19.0 & $17.9-20.6$ & $19.1 \pm 0.98$ \\
\hline Interorbital width & 36.7 & $36.6-41.2$ & $39.0 \pm 1.66$ \\
\hline Mandibullary width & 14.9 & $13.0-15.6$ & $14.8 \pm 0.76$ \\
\hline \multicolumn{4}{|l|}{ Other percents } \\
\hline Snout length/orbital diameter & 31.5 & $28.0-33.6$ & $30.7 \pm 1.71$ \\
\hline Interorbital width/o & 51.7 & $43.8-54.7$ & $49.1 \pm 3.78$ \\
\hline Interorbital width/mandibullary width & 40.5 & $33.6-41.2$ & $38.0 \pm 2.39$ \\
\hline Predorsal length/first dorsal-fin spine length & 63.8 & $63.8-84.9$ & $72.2 \pm 5.72$ \\
\hline Predorsal length/first pectoral-fin spine length & 77.4 & $68.4-82.4$ & $78.4 \pm 4.13$ \\
\hline Predorsal length/lower caudal-fin umbranched ray length & 60.7 & $59.1-93.6$ & $76.9 \pm 14.25$ \\
\hline Caudal-peduncle depth/adipose-fin spine length & 82.0 & $82.0-98.0$ & $89.8 \pm 4.78$ \\
\hline Caudal-peduncle length/caudal-peduncle depth & 35.1 & $32.7-39.6$ & $35.7 \pm 1.79$ \\
\hline Cleithral width/mandibullary width & 15.3 & $13.6-17.1$ & $15.6 \pm 1.01$ \\
\hline Dorsal-fin base length/interdorsal length & 52.3 & $43.9-59.3$ & $52.8 \pm 4.57$ \\
\hline Lower lip length/lower lip width & 31.0 & $31.0-36.2$ & $33.3 \pm 1.85$ \\
\hline Counts & Holotype & Range & Mode \\
\hline Median plate series & 24 & $23-25$ & 24 \\
\hline Predorsal plates & 3 & $3-3$ & 3 \\
\hline Dorsal plates below dorsal-fin base & 8 & $7-8$ & 7 \\
\hline Plates between dorsal and adipose fin & 4 & $4-6$ & 5 \\
\hline Plates between adipose and caudal fin & 4 & $4-6$ & 4 \\
\hline Ventral plates between end of anal-fin base and caudal fin & 13 & $11-13$ & 13 \\
\hline Premaxillary teeth & 16 & $10-18$ & 16 \\
\hline Dentary teeth & 19 & $13-19$ & 13 \\
\hline
\end{tabular}

Dorsal fin moderate; V-shaped spinelet followed by flexible spine and seven branched rays; distal tips of posterior rays just reaching preadipose plate; its posterior border straight. Adipose fin curved posteriorly; relatively well-developed. Pectoral fin with a slightly medially curved spine and six branched rays; its posterior border straight. Pectoral-fin spine covered with well-developed odontodes more developed distally and in larger specimens; when medially adpressed reaching about half pelvic-fin unbranched ray length. Pelvic fin with slightly medially curved and ventrally flattened unbranched ray and five branched rays; when medially adpressed reaching a line about one-third anal-fin unbranched ray; its border almost straight. Anal fin reaching sixth plate after its origin; its border straight. Caudal fin with two outer unbranched rays and 14 inner branched rays; furcate, with ventral lobe longer than dorsal one.

Color in alcohol. Ground color of dorsal surface of head and body grayish. Head, dorsum and flanks covered with many dark transverse bars of irregular forms, with several of the bars merging randomly. On head the bars are closer to each other, sometimes fused and covering most of head; towards posterior portions of body the bars are more conspicuous, and increase in width and in distance from each other. Dorsal, pectoral, pelvic and caudal fins with four to five usually conspicuous dark bands. Adipose fin with one dark transversal band and anal fin with two dark bands.

Color in life. The specimen ZSM 39427 (Fig. 3) when alive presented small and irregular dark saddles scattered over dorsal region of head, predorsal region and pectoral fin. The posterior region of body and remaining fins have wide and irregular, but not reticulate, dark transversal saddle-like bands. Dorsal, pelvic and caudal fins presented three to four dark conspicuous irregular bands.

Etymology. The specific name refers to the genus Peckoltia, which includes species with dark saddles similar to that found in the new species. The word comes from the name of the genus proposed by Miranda-Ribeiro (1912), honoring Mr. Gustavo Peckolt, plus the Greek suffix -öides meaning to resemble. 


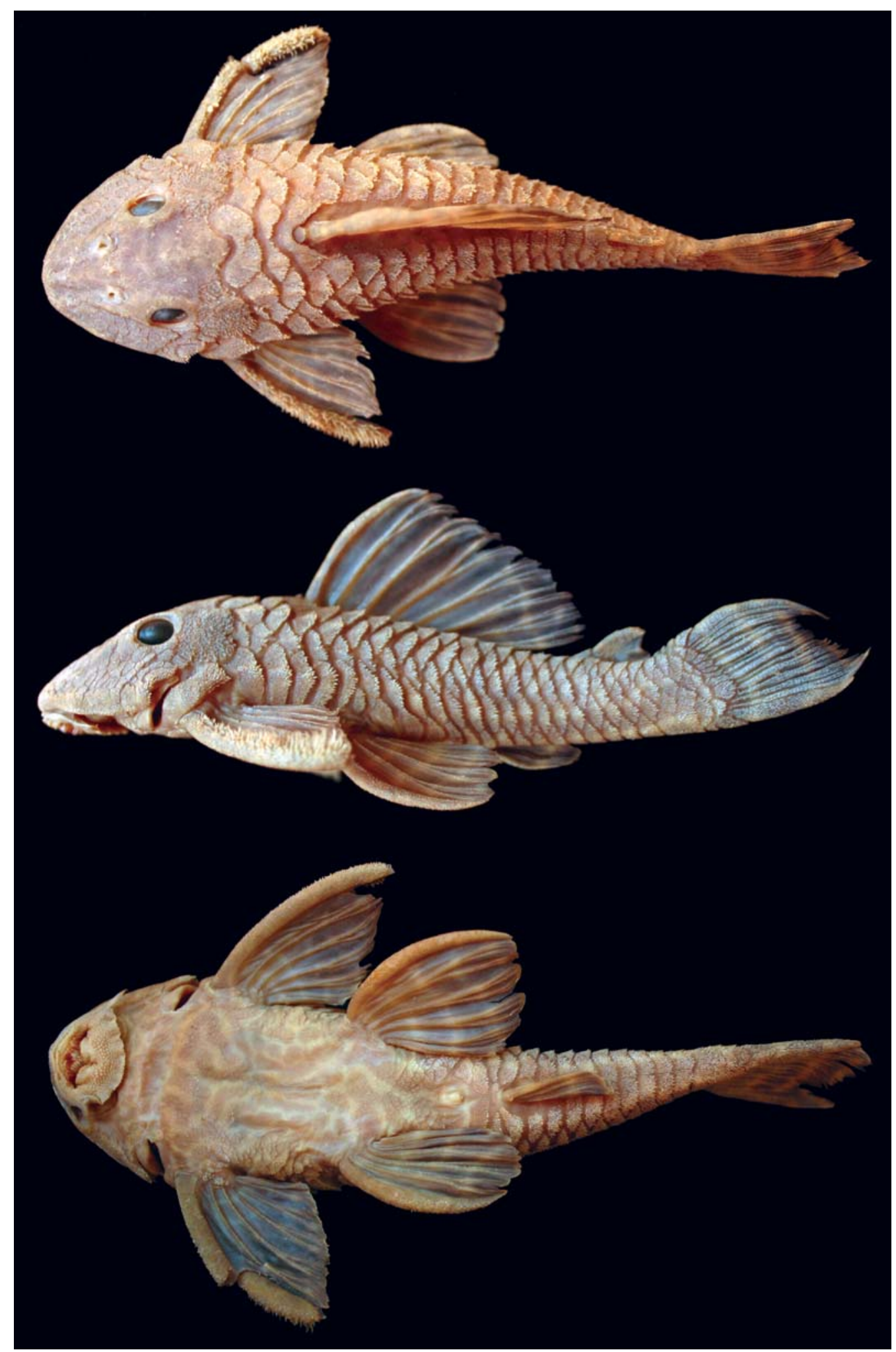

Fig. 2. Hypostomus peckoltoides, holotype, MZUSP 105226, $110.7 \mathrm{~mm}$ SL, from the rio Cuiabá, upper rio Paraguai basin, Mato Grosso State, Brazil.

Distribution and habitat. Hypostomus peckoltoides is known from its type-locality, rio Cuiabá, upper rio Paraguay basin, Brazil. The rio Cuiabá is formed by the joint of the rio Cuiabazinho and the rio Manso, nearby Nobres City, to be the first major tributary to the rio Paraguay, where it flows south of Cuiabá Municipality. These environments have turbid water, rocky with sand substrate, and variable remnant riparian vegetation. The new species was found syntopically 


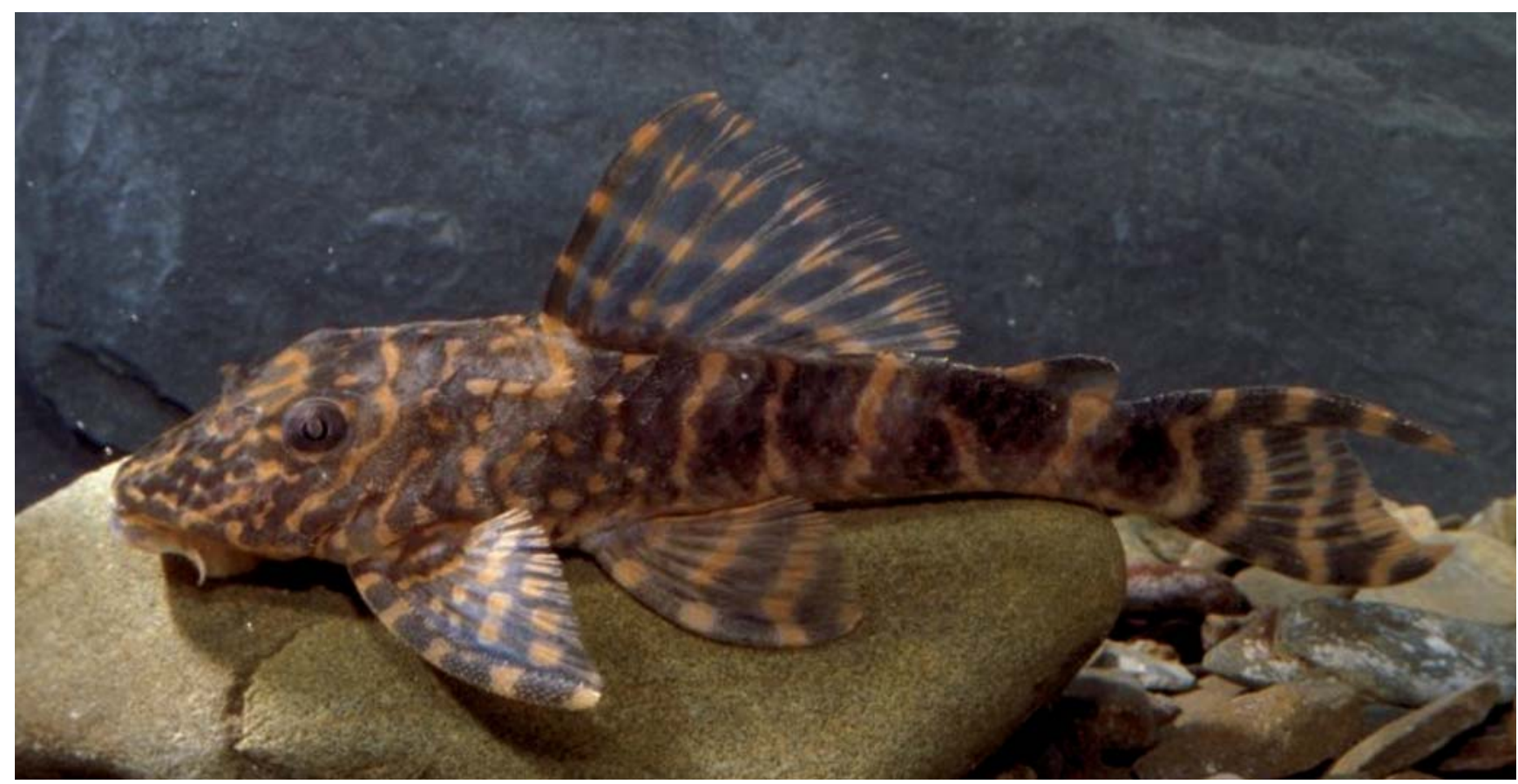

Fig. 3. Hypostomus peckoltoides, paratype, ZSM 39427, 90.3 mm SL. Photographed alive by Andre Werner.

occurring with $H$. boulengeri, $H$. cochliodon, $H$. latifrons, $H$. latirostris, $H$. regani and another putative undescribed species of Hypostomus.

\section{Discussion}

Hypostomus peckoltoides is diagnosed by its unusual saddling coloration. In fact, there is not a consensus if the color pattern is composed by dark bands over a clearer background or by pale bands over a darker background. Probably, the presence of younger specimens could allow a strict decision. However, whatever the color pattern is it will be a diagnostic character from any congener, so we decided to consider the new species as a dark-saddled species.

In hypostomines, dark saddles on the head and trunk are mainly found in some representatives of the genus Peckoltia, in Pseudancistrus kwintii Willink, Mol \& Chernoff from the rio Coppename in Surinam, and in a putative undescribed species of Hemiancistrus from the rio Madeira in Brazil. The new species also have a color pattern very similar to two Hypancistrus species from Venezuela, $H$. furunculus Armbrustrer, Lujan \& Taphorn and H. debiliterra Armbruster, Lujan \& Taphorn (see fig. 1, p. 63 in Armbruster et al., 2007). However, Hypostomus peckoltoides is distinguished from ancistrins with similar colors by lacking hypertrophied cheek odontodes. In Hypostomus there is currently a single occurrence of dark bars as observed in juveniles of Hypostomus latifrons (Fig. 4a). In H. latifrons from the rio Paraguay basin, dark saddles are a conspicuous character from the snout to caudal fin on specimens up to $65.0 \mathrm{~mm} \mathrm{SL}$, thereafter the dark-saddled coloration gradually fade to a dark-spotted pattern (Fig. 4b). Hypostomus peckoltoides is promptly diagnosed from $H$. latifrons by several features in addition to the dark-saddled coloration on adults, such as: by the presence of a single predorsal plate bordering supraoccipital $v s$. three; by a smaller orbital diameter to interorbital width ratio $(17.9-20.6 \%$ vs. $22.7-$ $31.2 \%$ ); and by apparently reaching a smaller standard length at maturity (110.7 vs. 287.0; data of H. latifrons from Weber, 1986a). Dark and pale banding pattern are homoplastic characters with independent origins among Ancistrini and Hypostomini. Thus, despite the fact that young $H$. latifrons share the saddled pattern with $H$. peckoltoides, the large amount of morphological differences lead us to doubt a close relationship between these two species. Besides, to establish the positioning of the new species within the genus is far beyond the aim of this work as, according to Armbruster (2004), phylogeny of Hypostomus is still unresolved.

Three to five wide dark bars are also reported on caudal fin of H. nigromaculatus (Schubart) from the rio Mogi Guaçu, upper rio Paraná basin, Brazil; however, no dark saddles have ever been found on thousands of specimens analyzed from the several sampled streams along that basin. The dorsal portion of head and trunk of H. nigromaculatus have scattered, round dark spots, which become larger posteriorly.

The dark bars observed in H. peckoltoides and those in young specimens of $H$. latifrons can not be confounded with the stress coloration marks that usually appear on disturbed species of the genus Hypostomus. Zawadzki et al. (2008) reported it in some few preserved specimens of $H$. faveolus Zawadzki, Birindelli \& Lima bearing two to five oblique dark saddles on trunk. The stress coloration is an independent color trait controlled by some unknown genetic-hormonal 


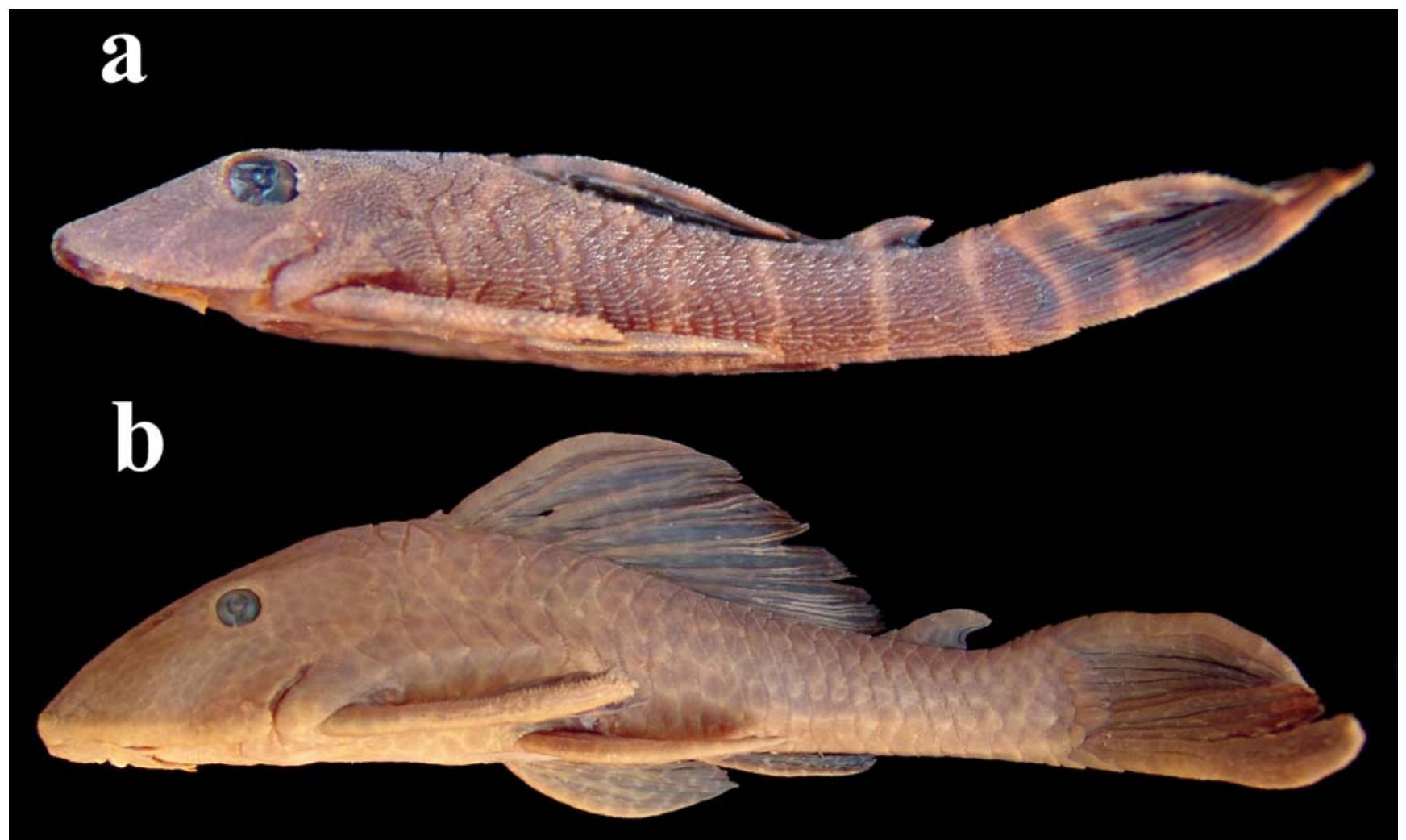

Fig. 4. Lateral view of Hypostomus latifrons, NUP 2274: a) young specimen, $42.2 \mathrm{~mm} \mathrm{SL}$; b) large specimen, $200.4 \mathrm{~mm}$ SL.

triggers which highlight or fade the oblique bars in response to fish excitement. Stress coloration can be usually seen in specimens of the $H$. plecostomus group as $H$. ancistroides, H. boulengeri, H. plecostomus among others (pers. obs.).

Many species have been described recently in the rio Cuiabá basin. Shibatta \& Pavanelli (2005) described Batrochoglanis melanurus from the rio Cancela; Carvalho et al. (2008) described Hyphessobrycon rutiliflavidus from córrego Pipa; Graça et al. (2008) described Characidium nupelia from tributaries to the rio Cuiabá and; Pavanelli et al. (2009) described Metynnis cuiaba from the drainages of the rios Cuiabá and Manso. The discovery of $H$. peckoltoides reinforces the upper rio Paraguay basin as a region of undescribed diversity, and the area deserves more survey efforts in the headwater streams and also in the main river channels.

Comparative material. Brazil: Mato Grosso State: Hypostomus boulengeri: NUP 414, 3, 165.8-175.6 mm SL, rio Manso, rio Paraguay basin. H. cochliodon: NUP 2274, 2, 42.2-200.4 mm SL, rio Manso, rio Paraguay basin. NUP 3602, 1, $153.8 \mathrm{~mm}$ SL, rio Manso, rio Paraguay basin. H. latirostris: BMNH 1892.4.20.26-27, 2, syntypes, 137.2-159.3 mm SL, rio Jangada, rio Paraguay basin. H. mutucae: MCP 28669, holotype, $67.7 \mathrm{~mm}$ SL, rio Mutuca, rio Paraguay basin. H. ternetzi: BMNH 1895.5.17.64, holotype, $210.2 \mathrm{~mm} \mathrm{SL}$, rio Paraguay, rio Paraguay basin. Rondônia State: Hemiancistrus sp.: UFRO-I 657, 3, 113.7-119.0 mm SL, rio Bamburro, rio Madeira basin. Peckoltia bachi: UFRO-I 46, 1, $94.3 \mathrm{~mm}$ SL, Igarapé Belmont, rio Madeira basin. P. brevis: UFRO-I 577, 1, $77.0 \mathrm{~mm} \mathrm{SL}$, rio Abunã, rio Madeira basin. P. vittata: UFRO-I 477, 1, $46.2 \mathrm{~mm}$ SL, rio Abunã, rio Madeira basin. São Paulo State: Hypostomus ancistroides: MZUSP
2131, 4, 95.6-165.1 mm SL, rio Tatuí, upper rio Paraná basin. $H$. nigromaculatus: MZUSP 22674, 9, 43.8-75.9 mm SL, cachoeira de Emas, rio Mogi-Guaçu, upper rio Paraná basin. H. regani: $\mathrm{BMNH}$ 1905.6.7.3, holotype, $174.2 \mathrm{~mm} \mathrm{SL}$, rio Piracicaba, upper rio Paraná basin. Argentina: H. cordovae: BMNH 1878.4.4.1, holotype, 178.3 mm SL, Cordova, rio Paraná, rio Paraná basin. H. laplatae: BMNH 1908.8.29.17, 1, $207.3 \mathrm{~mm}$ SL; río de La Plata, La Plata basin. Paraguay: H. dlouhyi: MHNG 2229.43, holotype, $139.5 \mathrm{~mm} \mathrm{SL}$, río Yguazú, upper rio Paraná basin. H. latifrons: MHNG 2256.67, holotype, $228.2 \mathrm{~mm} \mathrm{SL}$, río Araguay-guazú, río Paraguay basin. $H$. microstomus: MHNG 2367.90, holotype, $197.5 \mathrm{~mm} \mathrm{SL}$, rio Paraná, Itapua department. H. piratatu: MHNG 2265.03, holotype, $214.0 \mathrm{~mm}$ SL, Paraguari department, río Paraguay, río Paraguay basin. Surinam: H. plecostomus: RMNH 18240, invalid neotype - Boeseman, 1968, $121.4 \mathrm{~mm} \mathrm{SL}$, rio Suriname. Pseudancistrus kwinti: FMNH 116976, holotype, $94.3 \mathrm{~mm} \mathrm{SL}$, Surinam, rio Coppename. Uruguay: H. commersoni: MNHN A.9444, holotype, $425 \mathrm{~mm}$ SL, río de la Plata, La Plata basin.

\section{Acknowledgements}

The authors are grateful to Alessandro G. Bifi and Weferson J. Graça for comments and suggestions on the manuscript. We also thanks Edson K. Okada, Samuel Veríssimo, and Wladimir M. Domingues for collecting samples in the rio Cuiabá; Jaime L. Pereira for making the map; Andre Werner for kindly providing the alive picture; Dirk Neumann and Ulrich Schliewen (ZSM) for loaning specimens of Hypostomus; Patrick Campbell and Gordon Howes (BMNH), Patrice Pruvost (MNHN), and Margarete S. Lucena (MCP) for loan of comparative material and hosting 
museum visits. Nupélia and FURNAS Centrais Elétricas S/A provide us with logistical support. This study was partially supported by awards to CHZ from the US National Foundation (DEB-0315963) entitled Planetary Biodiversity Inventory: All Catfish Species (Siluriformes) - Phase I of an Inventory of the Otophysi, and grants to CHZ from the Conselho Nacional de Desenvolvimento Científico e Tecnológico, Proc. 308556/2009-7 to CSP and Proc. 306066/2009-2.

\section{Literature Cited}

Armbruster, J. W. 2004. Phylogenetic relationships of the suckermouth armored catfishes (Loricariidae) with emphasis on the Hypostominae and the Ancistrinae. Zoological Journal of the Linnean Society, 141: 1-80.

Armbruster, J. W., N. K. Lujan \& D. C. Taphorn. 2007. Four new Hypancistrus (Siluriformes: Loricariidae) from Amazonas, Venezuela. Copeia, 2007(1): 62-79.

Britski, H. A., K. Z. de S. de Silimon \& B. S. Lopes. 2007. Peixes do Pantanal: manual de identificação. Brasília, Embrapa, 230p.

Boeseman, M. 1968. The genus Hypostomus Lacépède, 1803, and its Surinam representatives (Siluriformes, Loricariidae). Zoologische Verhandelingen, 99: 1-89.

Boulenger, G. A. 1895. Abstract of a report on a large collection of fishes formed by Dr. C. Ternetz in Matto Grosso and Paraguay, with descriptions of new species. Proceedings of the Zoological Society of London, 2(34): 523-529.

Boulenger, G. A. 1897. Viaggio del Dott. Alfredo Borelli nel Chaco boliviano e nella Republica Argentina. III. Poissons. Bollettino dei Musei di Zoologia ed Anatomia Comparata della Reale Universitá di Torino, 12(279): 1-4.

Carvalho, F. R., F. Langeni, C. S. Miyazawa \& W. P. Troy. 2008. Hyphessobrycon rutiliflavidus n. sp., a new characid fish from the upper rio Paraguay, State of Mato Grosso, Brazil (Characiformers: Characidae). Zootaxa, 1674: 39-49.

Eigenmann, C. H. \& C. H. Kennedy. 1903. On a collection of fishes from Paraguay, with a synopsis of the American genera of cichlids. Proceedings of the Academy of Natural Sciences of Philadelphia, 55(56): 497-537.

Fricke, R. \& W. N. Eschmeyer. 2010. A guide to fish collections in the Catalog of Fishes electronic version, California Academy of Sciences, San Francisco. Available at: http://research.calacademy.org/ redirect?url=http://researcharchive.calacademy.org/research/ Ichthyology/catalog/fishcatmain.asp/. Accessed February 24, 2010.

Graça, W. J., C. S. Pavanelli \& P. A. Buckup. 2008. Two new species of Characidium (Characiformes: Crenuchidae) from Paraguay and Xingu River basins, State of Mato Grosso, Brazil. Copeia, 2008(2): 326-332.

Hollanda Carvalho, P., F. C. T. Lima \& C. H. Zawadzski. 2010. Two new species of the Hypostomus cochliodon group (Siluriformers: Loricariidae) from the rio Negro basin in Brazil. Neotropical Ichthyology, 8(1): 39-48.

Knaack, J. 1999. A New Species of Suckermouth Catfish (Hypostomus La Cépède, 1803) from the Mato Grosso, Brazil (Pisces, Siluriformes, Loricariidae). Tropical Fish Hobbyist, 45(11): 102-108.
Kner, R. 1854. Die Hypostomiden. Zweite Hauptgruppe der Familie der Panzerfische. (Loricata vel Goniodontes). Denkschriften der Mathematisch- Naturwissenschaftlichen Classe der Kaiserlichen Akademie der Wissenschaften in Wien, 7: 251286.

Leege, C. O. 1992. Der Rumpfpanzer der Panzerwelse und seine Skelettbeziehungen (Plecostomus angipinnatus n. sp., Callichthys callichthys L. und Corydoras paleatus Jen.). Jenäische Zeitschrift für Naturwissenschaft, 58: 145-270.

Miranda-Ribeiro, A. 1912. Loricariidae, Callichthyidae, Doradidae e Trichomycteridae. Comissão de Linhas Telegraphicas Estrategicas de Matto Grosso ao Amazonas, 16(5): 1-32.

Pavanelli, C. S., R. P. Ota \& P. Petry. 2009. New species of Metynnis Cope, 1878 (Characiformes: Characidae) from the rio Paraguay basin, Mato Grosso State, Brazil. Neotropical Ichthyology, 7(2): 141-146.

Regan, C. T. 1904. A monograph of the fishes of the family Loricariidae. Transactions of the Zoological Society of London, 17(1): 191-350.

Schaefer, S. A. 1997. The Neotropical cascudinhos: systematics and biogeography of the Otocinclus catfishes (Silurifiormes: Loricariidae). Proceedings of the Academy of Natural Sciences of Philadelphia, 148: 1-120.

Shibatta, O. A. \& C. S. Pavanelli. 2005. Description of a new Batrochoglanis species (Siluriformes, Pseudopimelodidae) from the rio Paraguai basin, State of Mato Grosso, Brazil. Zootaxa, 1092: 21-30.

Veríssimo, S., C. S. Pavanelli, H. A. Britski \& M. M. M. Moreira. 2007. Fish, Manso Reservoir region of influence, Rio Paraguai basin, Mato Grosso State, Brazil. Check List, 1(1): 1-9.

Weber, C. 1986a. Révision de Hypostomus boulengeri (Eigenmann $\&$ Kennedy), et deux espèces nouvelles de poissons-chats du Paraguay (Pisces, Siluriformes, Loricariidae). Revue suisse de Zoologie, 93(4): 979-1007.

Weber, C. 1986b. Les poissons-chats cuirassés de la sous-famille des Hypostominae du Paraguay. Unpublished M.Sc. Dissertation, University of Nancy, Nancy, 96p.

Weber, C. 2003. The Hypostominae. Pp. 351-372. In: Reis, R. E, S. O. Kullander \& C. J. Ferraris Jr. (Eds.). Check list of the freshwater fishes of South and Central America. Porto Alegre, Edipucrs, 729p.

Weber, C., S. Muller \& V. Mahnert. 1992. Harnischwelse Paraguays. DATZ, (Sonderheft Harnischwelse): 10-13.

Werner, A., W. Lechner \& J. Schmidt. 2005. Miniatlas - L-Welse L1 bis L400. Ruhmannsfelden, Bede-Verlag, 392p.

Zawadzki, C. H., J. L. O. Birindelli \& F. C. T. Lima. 2008. A new pale-spotted species of Hypostomus Lacépède (Siluriformes: Loricariidae) from the rio Tocantins and Xingu basins in central Brazil. Neotropical Ichthyology, 6(3): 395-402.

Zawadzki, C. H., E. Renesto, M. D. Peres \& S. Paiva. 2009. Allozyme variation among three populations of the armored catfish Hypostomus regani (Ihering, 1905) (Siluriformes: Loricariidae) from the Paraná and Paraguay river basins, Brazil. Genetics and Molecular Biology, 31(3): 767-771. 